\title{
The 'Do It Yourself' Paradigm: An Inquiry into the Historical Roots of the Neglect of Testimony
}

\author{
Emmanuel Alloa \\ University of St. Gallen, Switzerland \\ emmanuel.alloa@unisg.ch
}

\begin{abstract}
In contemporary social epistemology, the claim has been made that there is a traditional "neglect of testimonial knowledge," and that in the history of epistemology, firsthand self-knowledge was invariably prioritised over secondary knowledge. While this paper acknowledges some truth in these statements, it challenges the given explanations: the mentioned neglect of testimonial knowledge is based not so much on a primacy of self-knowledge, but that of self-agency. This article retraces some crucial chapters of this 'do-it-yourself' paradigm: it considers the imperative of autopsia in early Greek epistemology, history and medicine, and the early modern refashioning of the privilege of self-generated and self-taught (autodidactic) knowledge. A new picture emerges of how the emphasis on (self-)agency progressively shifted towards a focus on the self as the source of ultimate knowledge.
\end{abstract}

\section{Keywords}

testimony - self-knowledge - autopsy - autodidactic - Archaic Greek epistemology Renaissance - René Descartes - history - medicine

* University of Sankt Gallen, sHss, Philosophy, Unterer Graben 21, CH-9ooo St. Gallen, Switzerland. 


\section{The Neglect of Testimony: How Truly Pragmatic Is the 'Pragmatic Turn' in Epistemology?}

The following quote is sometimes attributed to Winston Churchill: "Never trust a statistic you haven't forged yourself." This anecdote is interesting in two respects, which ultimately make the same point. Firstly, Churchill apparently never dispensed this advice (he actually regarded statistics highly), but the quote was devised by the Nazi regime to discredit the British enemy. ${ }^{1}$ One might, then, say, 'never trust a quote you haven't forged yourself'. But secondly, if this sentence is still quoted so often, even though its forged nature has long been revealed, it may arguably point to a deep-rooted belief - the belief that there is nothing we are better acquainted with than that which we have done ourselves, with our own hands, or, more generally, by our own means. Trust is fine, but first-hand knowledge is better. In whatever way we consider the story of the alleged Churchill quote, it seems to confirm a human tendency to favour self-agency over second-hand knowledge: knowing by ourselves could stands in opposition to knowing through others, i.e. by hearsay, based on opinion and belief. While the latter is ultimately unverifiable, the former mode of knowledge alone guarantees that the acquisition of knowledge can be traced back to its source.

Yet such a deep-rooted persuasion is at odds with some of the recent developments in the humanities and social sciences. It is certainly not too bold a statement to say that a consensus has recently formed that bridges the usual divide between the history of science and philosophical epistemology. This consensus tends to question the long-standing privilege granted to first-person inquiry, and stresses the inherently social dimension of cognition instead. In opposition to a reductionist understanding of knowledge, which exclusively ties 'self-evidence' to the individual self, and to what might be called the idea of 'autopsy' ('seeing with one's one eyes'), many authors advocate intersubjective, pragmatic and mediated aspects of knowledge.

Indeed, we might accept that we know most things that we hold to be true not by ourselves, but through others. Whether gathered through personal oral testimony or through the media, through the questioning of witnesses or often-repeated pieces of information, some of our sturdiest beliefs - about our ancestors, the geography of the earth, or our position in the universe - have never been the object of any personal inquiry, since we take them for granted. As a matter of fact, some of our most personal facts and features will never be

1 Werner Barke, Ich glaube nur der Statistik... Was Winston Churchill über Zahlen und Statistik gesagt haben soll - und was er wirklich sagte (Stuttgart, 2011). 
directly accessible to us: when a customs officer asks us to fill out a form with our personal details, such as our date of birth, we simply repeat what has been handed down to us by others. Social epistemology has clearly shown to what extent our existence is determined by relations of trust which, by nature, are based on assumptions that we have not verified ourselves. If we were to strip the world bare of all facts that we have not checked first hand, we would be left with a heavily disfigured and scarcely recognizable environment.

This new consensus in social epistemology presents not only a discrepancy with the commonsensical reaction to the abovementioned Winston Churchill anecdote, it moreover conflicts with large parts of traditional epistemology. Social epistemologists are certainly right when they observe, in the history of knowledge, a traditional "neglect of testimony" (this trope was formulated by Jonathan Coady in his seminal study, and has since been repeated often). ${ }^{2}$ Undoubtedly, the "autoptic imagination" looks back upon a long history: ${ }^{3}$ according to one established opinion, true evidence is necessarily evidence one has verified for oneself; and advocates of social epistemology hold that this restrictive understanding of truth gave rise to a "solipsistic bias," which we still have not fully discarded. ${ }^{4}$ Truth is not something that 'lies around, out there' - it needs to be constructed, through intersubjectively shared practices. The current consensus could then be summarized as follows:

a. rather than just being recorded, knowledge needs to be produced.

b. (by and large) knowledge is to be socially produced.

In the wake of what could perhaps roughly be termed the 'pragmatic turn' of epistemology, and the shift towards socially shared practices of knowledge (the title of, for example, Steven Shapin's influential A Social History of Truth in itself is telling), the issue of testimony has come to play a crucial role in contemporary philosophical epistemology. ${ }^{5}$ In certain ways, testimony represents a litmus test for distinguishing individualistic epistemologies and social epistemologies, as Frederick Schmitt has noted:

2 C.A.J. Coady, Testimony: A Philosophical Study (Oxford, 1992), 13.

3 Anthony Pagden, European Encounters with the New World:From Renaissance to Romanticism (New Haven, CT, 1992), 5 .

4 Peter Lipton, "The Epistemology of Testimony," Studies in the History and Philosophy of Science, 29 (1998), 1-31.

5 Steven Shapin, A Social History of Truth (Chicago, IL, 1994). 
If individualism concerning testimony is defensible, then epistemology will remain in an important sense individualistic. And if it is not defensible, epistemology will have to be profoundly social, whatever may happen on other topics. ${ }^{6}$

The vast field of scholarship on testimony generally confirms that the second alternative has gained the upper hand. The broad evidence for our constant and inevitable reliance on others - verifying every premise would make practical living virtually impossible - has been considered a successful rebuttal of epistemic individualism, which holds that "social phenomena can be fully explained in terms of the motivations and actions of individual agents."7 Today, as Jennifer Lackey states, "the importance of testimony, both epistemological and practical, is nearly universally accepted," as it shows that the domain of cognition reaches far beyond the evidence a subject can purport to have seen "with her own eyes.8 If the testimony of others is, indeed, a valid source of knowledge, the way in which the epistemic process is understood needs to be reconsidered. Beyond the dichotomy of cognition and action, cognition itself is now largely considered an enactive, generative process, and not just the passive registration of a state of affairs. Communitarian epistemologists highlight that a testimonial utterance is not 'constative' but 'performative:' rather than stating that something is the case somewhere in the world, testimonies 'set up' facts in the world, thereby effectively generating them. ${ }^{9}$ Most scholarship on testimony thus confirms that epistemology must be seen not only in a pragmatic way, but also more specifically in its generative and intersubjective aspects, and that the new social epistemology contributes to put to ending the "dominance of an individualist ideology" which, according to Coady, dominated the Western, especially post-Renaissance world. ${ }^{10}$

Interestingly, current debates within philosophical epistemology are mirrored in the history of science. A large consensus has formed to see scientific discoveries not as the achievement of individual geniuses, but rather that of

6 Frederick F. Schmitt, "Socializing Epistemology: An Introduction through Two Sample Issues," in Frederick F. Schmitt, ed., Socializing Epistemology: The Social Dimension of Knowledge (Lanham, MD, 1994), 1-28, 4.

7 Axel Gelfert, A Critical Introduction to Testimony (London, 2014), 175.

8 Jennifer Lackey, "Testimony: Acquiring Knowledge from Others," in Alvin Goldman and Dennis Whitcomb, eds., Social Epistemology: An Anthology (Oxford, 2011), 71-91, at 71.

9 Martin Kusch, "Testimony in Communitarian Epistemology," Studies in History and Philosophy of Science, 33 (2002), 335-354, at 349. Peter J. Graham, "Can Testimony Generate Knowledge?" Philosophica, 78 (2006), 105-127. 
"thought collectives" (Ludwik Fleck), communities of scholars, convergent practices, technological parameters, and changes in mentality. ${ }^{11}$ Consequently, in Shapin's and Schaffer's seminal work Leviathan and the Air Pump, which discusses the experimental science of the seventeenth century, Thomas Hobbes appears as a helplessly obsolete epistemic individualist who still believes that only personal inquiry leads to knowledge; whereas Robert Boyle represents epistemology following the 'pragmatic turn,' after which advancement in knowledge is accepted to be a necessarily transindividual, collective process. ${ }^{12}$

A pragmatic turn has, then, unquestionably taken place, both in systematic and in historical epistemology. The aim of this paper is not to question the fact that this turn was a necessary development; to the contrary, it welcomes it. Its aim is, rather, to analyze whether one of the central assumptions that validated this 'turn' was not, in fact, flawed from the start. With regard to historical epistemology, as has been noted elsewhere, investigations of specialist groups of scholars - like those active in the context of the Royal Society in the seventeenth century - intended to demonstrate the necessarily collective nature of knowledge production risk entering a circular argument. ${ }^{13}$ Moreover, the fact that (as Shapin and Schaffer repeatedly stress) the Royal Society is formed by a community of experts whose authority as witnesses is grounded in the authority of the individual might raise some questions of whether expert collectives really provide the best argument against the putative individualism in epistemology. ${ }^{14}$ Similar criticisms might be voiced against the systematic-oriented approaches in philosophy. One cannot help but notice that the philosophical debate about testimony somewhat resembles that of the question of 'other minds,' e.g.: What are the conditions that give us access to what others know? Is it possible to find out on what grounds other minds know what they know? Under what circumstances might it be justified to rely on another individual's information? Merely transferring the task of securing knowledge to others is hardly sufficient for overturning the individualistic bias of traditional epistemology: however dependent on others reliabilistic positions may be, they of-

See e.g. Ludwik Fleck, "Scientific Observation and Perception in General," (1935), in Robert S. Cohen and Thomas Schnelle, eds. Cognition and Fact: Materials on Ludwik Fleck (Dordrecht, 1986), 47-58; Bruno Latour and Steven Woolgar, Laboratory Life: The Social Construction of Scientific Facts (Beverly Hills, CA, 1979); Andrew Pickering, The Mangle of Practice: Time, Agency, and Science (Chicago, IL, 1995); Lorraine Daston and Peter Galison, Objectivity (Chicago, IL, 2007).

Steven Shapin and Simon Schaffer, Leviathan and the Air-Pump: Hobbes, Boyle and the Experimental Life (Princeton, NJ, 1985).

13 Lipton, "The Epistemology of Testimony," 23.

14 See esp. Shapin and Schaffer, Leviathan and the Air-Pump, chap. 2. 
ten remain highly individualistic in their orientation, as Sanford C. Goldberg has convincingly argued. ${ }^{15}$ It may, therefore, not be sufficient to move towards a social epistemology while dismissing individualist ideology entirely: the involvement of more than one individual does not in itself prompt a move beyond individualism.

But another skeptical question should be considered here. In the wake of the pragmatic turn, the emphasis is not only on what is socially made; is it not also placed on the fact that knowledge is made, i.e., that it is the result of an action, and thus different from a putative traditional concept of knowledge. Hence traditional epistemology is not only an individualistic construct, but also static - two aspects which concurred in the image of a spectating subject impassibly registering the facts of the external world. But what if the pre-modern conception of knowledge was not this static in the first place? What if the common dichotomy between 'self' and 'other' was beside the point?

In what follows I shall suggest that, rather than focusing on actors, epistemological analysis should start with procedures. While much evidence points to the fact that the Western philosophical tradition has either "ignored testimony altogether or it has been cursory and dismissive," there are good reasons to believe that this did not primarily result from an individualistic bias, but rather from a tendency to define the valid generation of knowledge purely as self-generated knowledge. ${ }^{16}$ Instead of tracing back self-agency to the individual self and its allegedly unquestionable authority, it is worth investigating the specific parameters underlying this procedure. In retracing the historical vicissitudes of the 'ex propria industria' imperative, this article proposes a shift in perspective: first-hand knowledge was privileged because of its derivation from self-agency. Like theories of practice, epistemology had long been governed by the 'do it yourself' principle.

\section{Knowing about Oneself and Knowing Through One's Own Means}

Immanuel Kant was often asked by his students or hosts to write a few dedicatory words into their guest books or albums. As the years passed, he adopted the habit of finishing his notes with the following aphorism: 'Quod petis in te est. Ne te quaesiveris extra' - roughly, "That which you seek is within you; do not

15 Sandy Goldberg, Relying on Others: An Essay in Epistemology (Oxford, 2010), chap. 2.

16 Coady, Testimony, 6. 
search for it elsewhere."17 Unlike the Latin poets of his sources, Kant used this aphorism in reference not to a particular object of knowledge, but rather to a faculty of knowledge: here, the subject is not only that which needs to be investigated, and thus the object of knowledge in a manner of speaking; it is simultaneously the only means to achieving an insight. In contrast to the Delphic principle of gnotthi seauton ("know thyself"), the self is not the primary goal here, but first and foremost a 'medium' of knowledge acquisition. Thinking for oneself is not necessarily always thinking about oneself, but conversely, every true instance of thinking about oneself always requires thinking for oneself. In other words, a shift occurs, from knowing about oneself to knowing through one's own means. True knowledge, in this theory, is knowledge that one has acquired oneself; true knowledge is knowledge obtained through one's own effort.

Kant's emphasis on the use of one's own faculties, in turn, indicates a liberating possibility: since immaturity (Unmündigkeit) is 'self-incurred' (selbstverschuldet), it can be overcome through practice of one's own personal abilities. ${ }^{18}$ The primacy of autonomy - and of associated concepts like self-control, selfdetermination, or self-regulation - can only be understood fully if the self is considered a faculty, not an object. The liberated use of one's own abilities, such as thinking and acting for oneself, which is inherent to every single subject, nevertheless wavers between individuality and universality. Thinking for oneself, according to the first maxim of common sense, "means seeking the supreme touchstone of truth in oneself (i.e., in one's own reason)." ${ }^{\prime 19}$ In contrast, sapere aude refers to the courage "to use one's own understanding" without "the guidance of another." 20 Yet are the phrases 'one's own reason,' and 'one's own understanding,' not, in fact, oxymoronic? This oscillation between individuality and universality can be observed once more in Kant's elaboration on the topic of thinking for oneself, essentially "[t]hinking in everyone else's

17 The aphorism is, in fact, a textual portmanteau combining a verse fragment by Horace ("Quod petis, hic est") with a fragment from the Satires of another poet, Persius ("nec te quaesiveris extra"); Kant inscribed it in guest and autograph books, nine times altogether, from 1777 onwards. See Hans Vaihinger, "Erklärung der vier Beilagen," Kant-Studien, 9 (1904), 342-343.

18 Immanuel Kant, "Was ist Aufklärung?" in Horst D. Brandt, ed., and Ernst Cassirer, introd., Was ist Aufklärung: Ausgewählte kleine Schriften (Hamburg, 1999), 20; Hans Siegbert Reiss, ed., What Is Enlightenment? Kant: Political Writings (Cambridge, 1991), 54.

19 Immanuel Kant, "Was heißt sich im Denken orientieren?" (1786), in Brandt and Cassirer, Was ist Aufklärung, 6o; “What Does it Mean to Orient Oneself in Thinking?” in Allen W. Wood, ed., Religion and Rational Theology (Cambridge, 2001), 18. 
stead" (An der Stelle jedes andern zu denken). ${ }^{21}$ Self-induced submission to another's authority, where only the words and thoughts of others are adopted, is to be replaced with a form of emancipated reason that no longer adopts another's thoughts uncritically, while retaining the ability to speak on everyone's behalf.

This criticism of heteronomous representation, and thus alien authority, is juxtaposed with the overall representativeness of one's own reasoned thoughts. Consequently, autonomy and representativeness cannot be placed into opposition a priori. The question of enactment alone is sufficient to distinguish selfdetermination from the submission to alien authority. While it is possible to generalize from the principle of any action carried out on one's own grounds and thus to make it valid for virtually everybody, anything adopted from others will always be marred by the fact that its origin cannot be verified - one is reminded of the motto of the Royal Society of Great Britain "Nullius in verba," "Take nobody's word for it." Moreover, every adoption of exterior knowledge holds the risk of outside encroachment. Those who accept as a fact things they cannot verify for themselves necessarily surrender, in exchange, some of their autonomy to an alien entity.

In agreement with Kant, Diderot defines true knowledge as knowledge acquired through one's own faculties. An autonomous person is defined as someone who "dares to think for himself $[. .$.$] and admits nothing that is not based$ on the testimony of his experience and his reason."22 According to Jakob Thomasius's seventeenth-century theory of 'eclecticism,' upon which Diderot bases his own, there are two further possible sources of knowledge acquisition in addition to penser de soi-même (thinking for oneself): firstly, sense experience, and secondly, derived knowledge, or deductive reasoning based on one's own faculty of understanding. These passages demonstrate the lasting effects of a fundamental epistemological decision. If one must be able to provide an account of every acquired piece of knowledge, and if any epistemological content must have a traceable basis, then there are precisely two possible sources of true knowledge acquisition: direct perception and deductive reasoning. As such, true knowledge is always acquired first hand, since second-hand knowledge precludes authenticity. This view, predominant in epistemology and explicitly formulated during the Enlightenment, underlines the 'neglect of testimony' repeatedly affirmed in the philosophical testimony debate. Beliefs

21 Immanuel Kant, Handschriftlicher Nachlass, Refi. 2564; Akademie-Ausgabe [=AA] (Berlin, 1900 sqq.), vol. 16 (1924): 419, l. 1.

22 René Diderot, "Eclecticisme," in Encyclopédie ou dictionnaire raisonné des sciences, des arts et des métiers (Paris, 1755), vol. 5, 270. 
that are merely passed down from others but cannot be personally confirmed are relegated to the realm of transmission, and are not investigated further. Since they derive from an outside source, they cannot claim a status of knowledge, and should therefore be considered, at the very most, opinions.

Plato's Theaetetus illustrates the distinction between true episteme and mere doxa using the example of court witnesses. In order to establish the facts of the case, judges are obliged to refer to other people's testimony. Yet the court's ability to reach a verdict and arrive at facts that make a sentence legally enforceable is one thing; true knowledge is another. ${ }^{23}$ According to Jonathan Barnes, who provided an insightful comment for these passages, facts witnessed by others are certainly the most abundant form of knowledge. However, in his view, philosophical knowledge must be acquired in a more rigorous manner:

No doubt we all do pick up beliefs in that second hand fashion, and I fear that we often suppose that such scavenging yields knowledge. But that is only a sign of our colossal credulity: the method [...] is a rotten way of acquiring beliefs, and is no way at all of acquiring knowledge. ${ }^{24}$

A focus on procedure, rather than on the actor, allows a potentially interesting shift in perspectives. While agreeing with the diagnosis of a historical 'forgetfulness of testimony' in large portions of Western epistemology, this paper argues that the traditional rationale put forward to explain it - the supposed individualistic bias - does not sufficiently address the problem. The common obsession with individualism has concealed the fact that most epistemological debates (not just in philosophy, but also in many other fields of knowledge) do not so much revolve around the actors than around the procedures of knowledge acquisition. The article aims to explore an alternative hypothesis: what if the forgetfulness of testimony maintained in the testimony debate of Western epistemology were not caused by a primacy of the individual, but rather by a primacy of self-agency?

Primacy of self-agency is best expressed by Descartes's adage according to which true knowledge is necessarily knowledge acquired ex propria industria ('through one's own effort'). In what follows I will reconstruct some (exemplary and yet rather sporadic) moments from the timeline along which the 'do it

\footnotetext{
23 Plato, Theaetetus, 210b; in Plato, Theaetetus and Sophist, trans. H.W. Fowler (Cambridge, MA, 1980).

24 Jonathan Barnes, "Socrates and the Jury: Paradoxes in Plato's distinction between Knowledge and True Belief II," Aristotelian Society Supplementary, 54 (1980), 193-206, at 200.
} 
yourself' principle was progressively consolidated. Starting with a central topos of early Greek epistemology, the imperative of autopsia, this investigation shall then be extended to the different fields of history and medicine, before moving on to the early modern reshaping of this privilege of self-generated knowledge, and finally the topic of self-taught (autodidactic) knowledge. I will then argue, within the theme of the propria industria, the fact that the self ('proprium') has been given more attention was to the detriment of the industria. However, as the conclusion shall show, there is no need to tie or subordinate the generation (industria) to the private self. From a source of knowledge, the self turns into a means for knowledge - a medium of knowledge which, as it turns out, competes with many others. Via the phenomenon of testimonial knowledge, a 'de-centering' of individual subjectivity indeed takes place, but in a different way from those to which social epistemologies had accustomed us.

\section{Autos oida: With One's Own Eyes}

True knowledge is unmediated knowledge: this familiar trope can be traced back to some of the earliest extant sources of Greek culture. The connection between visual perception and mental understanding pervades Greek thought, even as early as in the pre-classical period. ${ }^{25}$ Homer's topical appeal to the Muses showcases the discrepancy between the omniscience of the gods and the ultimate contingency of the poet, who was not personally present at the time at which the events he narrates happened, and therefore relies on alien information:

Tell me now, Muses, dwelling on Olympos, as you are heavenly, and are [present, pareste] everywhere, and everything is known to you [iste te panta] - while we can only hear the tales [kleos] and never know [oude ti ismen $]^{26}$

25 Bruno Snell, Die Ausdrücke für den Begriff des Wissens in der vorplatonischen Philosophie (Berlin, 1924); Kurt von Fritz, "Noeô, Noein and Their Derivatives in Pre-Socratic Philosophy (Excluding Anaxagoras)," Classical Philology, 40 (1945), 223-242; Herman Fränkel, Dichtung und Philosophie des frühen Griechentums (Munich, 1962); Bruno Snell, "Wie die Griechen lernten was geistige Tätigkeit ist," Der Weg zum Denken und zur Wahrheit: Studien zur frühgriechischen Sprache (Göttingen, 1978), 26-32.

26 Homer, The Iliad, II, 484-6; in Homer, The Iliad, trans. Robert Fitzgerald (Garden City, NY, 1974). 
This passage is illuminating in several respects. What the muses know (iste) is, literally, what they have seen (iste is a form of eido/oida, 'to behold,' in the perfect tense); moreover, the act of beholding requires personal presence (parousia). The mortal poet on the other hand is doomed to gather the information for his narrative from an alien, and therefore uncertain, source. His knowledge is a derived knowledge from hearsay (as the text states, he believes the kleos, the 'tales,' a term etymologically derived from the word for hearing, according to the proto-Indo-European root *kleu). As a rumor, then, this is without origin, like a rustling in the forest. Belying Derrida's general claim about logocentrism according to which voice is always tied to presence (which then Derrida later extended to 'phono-photo-logocentrism,' which would include both the verbal and the visual), the Homeric passage rather suggests a metaphysical gap between the auditory and the visual. The auditory lacks a clear location and an unambiguous author, it floats indefinitely without clear spatial anchoring nor accountable authorship, since it can be echoed by many intermediary voices; the visual, however, does not accommodate temporal distance and requires physical testimony, the actual presence of visual parousia.

This dichotomy between the gods' knowledge on one hand, which is comprehensive due to its presentist nature, and humans' mediated, unsupported opinion on the other, was later reiterated by Xenophanes, who stated that a god remains "ever in the same place moving not at all," and that nevertheless - or therefore - "all of him sees, all thinks, all hears." ${ }^{27}$ Through their own effort, humans may not be able to acquire all knowledge - an emphasis on the finitude of man that also permeates the blind rhapsode's trope; but the invocation of a divine source lends human words their legitimacy. As such, alien testimony was entirely permissible for humans in ancient times (and was, in fact, even necessary), provided that the witness's authority remained unchallenged, and that it was possible to trace a definitive chain of transmission. At the same time, the word of truth must be traced back to a genuine and particular moment, to a witness who had "shared it" himself (autos pareōn). ${ }^{28}$ This emphasis on the oral tradition, however, places total priority on the sense of vision, as exemplified by the genealogy episode in the Iliad. After an extended presentation of family trees, which could be considered a veiled allegory for the epic's unbroken destiny of transmission, Aeneas addresses Achilles:

\footnotetext{
27 Hermann Diels and Walther Kranz [=DK], eds., Fragmente der Vorsokratiker (Berlin, 1903), 26 , respectively fragment B 26 and B 24 .

28 Homer, Odyssey, 8, 510; in Homer, The Odyssey, trans. Robert Fitzgerald (Garden City, NY, 1963).
} 
Each knows about the other's birth and parents

from the old tales of mortals that we've heard;

you'll never see my parents nor I yours. ${ }^{29}$

Despite the necessity of hearsay, the privileged place of seeing for oneself remains fully intact. Heraclitus simply reasserts this with an aphorism: "The eyes are more accurate witnesses than the ears." ${ }^{30}$ Nevertheless - and this cannot be emphasized enough - the distinction in question is not really a contest between the senses but rather a discrepancy between direct and mediated faculties. Those who repeat what they have heard inevitably speak with borrowed voices, whereas one cannot transmit what one has seen to others without rendering it in an auditory form. Thus, to see at all is to see for oneself. For Rémi Brague, the prioritization of sight is "not an unwarranted preference for a particular sense [...]. The reason the Greek world indisputably favored vision is because it better satisfied the requirements of the ideal of direct knowledge."31 It is this ideal of directness that justifies the dominance of that autos oida, that "self-seeing," which was referenced by Homer, and subsequently fixed into a concept. ${ }^{32}$

As Hermann Fränkel first demonstrated, what began with Homer as an expression acquired conceptual valence with Xenophanes of Colophon in the latter half of the sixth century вС. ${ }^{33}$ In a passage that might remind modern readers of Descartes, Xenophanes wrote that all knowledge consists of "clear insight," and therefore only things that one has seen oneself (autos oida) can be considered insight. ${ }^{34}$ Inherent in this passage is a rejection of all forms of religious or occult revelation, or soothsaying ('manticism'). ${ }^{35}$ The term "presence," as Robert Flacelière has shown, was affected by this. Previously, divine manticism had served to compensate for a lack of personal presence; the word mantike, which derives from manía (madness), restores a type of presence that the seeker is missing. The soothsayer is possessed by a god that essentially resides within his or her body, and provides direct access to divine revelation. ${ }^{36}$

\footnotetext{
29 Homer, Iliad, 20, 203-205.

$30 \quad \mathrm{DK}, 22$, fragment $\mathrm{B} 101$.

31 Rémi Brague, Introduction au monde grec: Etudes d'histoire de la philosophie (Paris, 2008), 88.

32 Homer, Odyssey, XIII, 273 and Iliad, XVII, 687.

33 Fränkel, Dichtung und Philosophie des frühen Griechentums, 381.

34 DK, 21, fragment B 34.

35 For the testimony in Aetius and Cicero, see James H. Lesher, "Xenophanes' Scepticism," Phronesis, 23 (1978), 1-21, at 7.

36 Robert Flacelière, Devins et oracles grecs (Paris, 1961), 33
} 
According to Fränkel, by rejecting manticism, Xenophanes "made the chasm between here and yonder unbridgeable." ${ }^{37}$

Xenophanes' Fragment 34, with its critique of knowledge, was one of the most frequently cited texts in antiquity. Both Plato and Aristotle made reference to it, while Sextus Empiricus even calls Xenophanes the founding father of scepticism. Whether Xenophanes should, indeed, be regarded as a sceptic is contested among scholars today. ${ }^{38}$ Indisputably, though, it was thanks to Xenophanes that first-hand experience was valued higher than experience derived from alien authorities, and his view had both a momentous and lasting impact. The development of the concept of autos oida can be traced through the dichotomies developed in various schools of thought, foremost in medicine, to which we shall attend in a moment, and in historiography, with which I will start.

\section{Historiography: The Histor as Eyewitness}

Xenophanes was well known for his criticism of Homer, which by extension questioned the oral tradition, which he contrasted with first-hand experience. Centuries later, Porphyry wrote the following in his commentary on Homer:

To see with one's eyes [idein ophthalmoisin] is dictinct from seeing something through one's imagination, just as in dreams too we think we see something and we refashion the narratives of others who have told them. ${ }^{39}$

While somewhat redundant with regard to the sensory experience described, the text makes instrumental use of the dative in ophthalmoisin ('with one's own eyes'), which might indicate that, here, self-action is once more highly regarded. This expression was originally reserved almost entirely for extraordinary events. Porphyry's later testimony shows the semantic shift of the expression ophthalmoisin horran in the course of the classical period: originally used for events in which someone, quite literally, would not believe his or her eyes,

37 Hermann Fränkel, “Xenophanesstudien," Hermes, 60 (1925), 174-192.

38 Ernst Heitsch produced some valid arguments for an anti-sceptic reading in Ernst Heitsch, "Das Wissen des Xenophanes," Rheinisches Museum für Philologie, 109 (1966), 193235 .

39 Porphyry, Questionum Homericarum ad Iliadem pertinentium reliquias, ed. Hermann Schrader (Leipzig, 1880), 75,28-76,1. 
by the end of the fifth century $\mathrm{BC}$ the phrase had become a maxim applied to ordinary factual knowledge. ${ }^{40} \mathrm{~A}$ historian, moreover, is literally a person who has seen with his own eyes: the moniker derives from the verb historein, "to see." Hegel later pointed out that early historians only described matters "of living and immediate interest in the personal experiences and external environment of men."41

Herodotus, whom Cicero posthumously declared the founding father of history, describes his understanding of the term historein. Whereas for Heraclitus, somewhat surprisingly, the defining feature of historein was Pythagorean philosophy, Herodotus's understanding of the same imposes two conditions: ${ }^{42}$ that of on-site investigation, and that of first-hand experience. In his Histories, Herodotus reports that on his journey down the Nile, he had traveled and 'seen for himself' (autoptēs) the country as far as Elephantine, but had learned everything about territories beyond that point by asking locals, i.e. orally (akoei historeōn). He supplements his narrative with tales from older Egyptian sources, notably offset by the admission that "[h]itherto my own observation and judgment and inquiry are the vouchers for that which I have said; but from this point onwards I am about to tell the history of Egypt according to that which I have heard."43

Thucydides phrases the ideal of autopsia in a similar manner. A historian must distinguish between 'remote antiquity' (pany palaia), the description of which necessarily relies on hearsay (akoai logōn), and more recent events, for which contemporaries who have seen (opsis) things for themselves and can consult their own 'experience' (autoi xyniste) are available. ${ }^{44}$ This controls the general tendency by some to "deal with traditions, even traditions of their own country, [by] receiv[ing] them all alike as they are delivered, without applying any critical test whatever." 45

40 Guido Nenci, "Il motivo dell'autopsia nella storiografia greca," Studi Classici e Orientali, 3 (1953), 14-46; Guido Schepens, L'autopsie dans la méthode des historiens grecs du Ve siècle av. Jc (Brussels, 1980); François Hartog, "The Witness and the Historian," in Sølvi Sogner, ed., Making Sense of Global History (Oslo, 2001), 320-337.

Georg Wilhelm Friedrich Hegel, Vorlesungen zur Philosophie der Geschichte, in Eva Moldenhauer and Karl Markus Michel, eds., Werke (Frankfurt/Main, 1971), vol. 12, 4; Hegel, Lectures on the Philosophy of World History, trans. H.B. Nisbet (Cambridge, 1975), 13. Heraclitus, DK, 22, fragment B 129.

43 Herodotus, Histories, 2, 99, 1; in The Histories, trans. A.D. Godley, 4 vols. (Cambridge, MA and London, 1946).

Thucydides, History of the Peloponnesian War 2, 73, 2; in History of the Peloponnesian War, ed. and trans. C.F. Smith (Cambridge, MA, 1921).

45 Ibid., 1, 20, 1. 
Polybius was the last to voice the imperative of first-hand experience so explicitly. ${ }^{46}$ Castigating armchair historians, he asserted that any true writing of history must be based on the historian's own witnessing. However, as Polybius concedes, the topic of autopsia is complicated by one further factor: witnessing a maritime battle is not alike to comprehending its military tactics and maneuvers. In this case, even if an uninvolved onlooker were "present, he would simultaneously be absent." 47 Thus, autopsia must be matched with autopatheia (self-experience) in order to be complete. In his account of wartime developments of 220 BC Polybius wrote that he "was not only an eyewitness [autoptēs], but a participant [sunergos] in some of these events and responsible for others." 48 This remarkable passage demonstrates the aporia between the dual roles of the eye witness: on the one hand, they are a detached, but blind observer, and on the other, they are someone involved in the observed events, and therefore someone whose comprehension will always be biased. The empeiria (experience) called for by Polybius reflects this aporia in its very etymology. The $p e(i) r$ in empeiria refers to transit, yet someone who has personally undergone the events he describes can rarely assert an objective standpoint. Polybius's claim to a universal history and a concomitant tota simul field of vision pushes against the inherent boundaries of this aporia, since it would ultimately require the 'Olympian standpoint' that Lucian of Samosata would later theorize in his historiography. According to Lucian, the historian's position should be precisely that of Zeus, king of the gods, "surveying now the Mysians', now the Thracian horsemen's land."49

The methodological considerations of these Roman historians reveal why the insistence on first-hand acquaintance quickly devolved into an empty trope. According to Verrius Flaccus, a Roman grammarian and scholar in the reign of Augustus, historiography should never involve accounts of events in which one was personally involved ("quibus rebus gerendis interfuerit is qui narret" $).{ }^{50}$ Before this background, his judgment of Greek historians is ambiva-

46 Marie Laffranque, "L'œil et l'oreille: Polybe et les problèmes de l'information en Histoire à l'époque hellénistique," Revue philosophique, 93 (1968), 263-272.

Polybius, Histories, 12, 28; in The Histories, trans. Robin Waterfield (Oxford and New York, NY, 2010).

48 Ibid., 3, 4 .

49 Lucian of Samosata, How to Write History, in A.M. Harmon, K. Kilburn and M.D. Macleod, eds., Works (Cambridge, MA and London, 1913), vol. 6, 49. Parallels can be found in Lucian's description of the katáskopos who looks from high above, in the dialogue Charon, also known as The Observers. 
lent, since their concept of historia had comprised 'knowledge of present-day affairs' ("rerum cognitio praesentium"). ${ }^{51} \mathrm{~A}$ history of the present is a problematic concept, and Verrius Flaccus is not the only one to believe so. Even Polybius had acknowledged the limitations of simultaneity for the historian, insisting on the fact that the status of the eye witness was subject to both spatial and temporal limitations:

Events take place simultaneously all over the world, but it is impossible for one person to be in more than one place at the same time, and it is equally impossible for him personally to visit every part of the world and see what is special about them. ${ }^{52}$

Polybius continues with the questions of how to relate to informants, how to interrogate witnesses, and how to critically evaluate sources. He makes visible the paradox which all historians face invariably: in asserting to have verified all events narrated from a first-hand perspective, historians claim that their statements are facts independent from their individual perspectives.

\section{Medicine: The Concept of Autopsia}

According to Polybius, philosophers and students of nature were regularly accused by their contemporaries of explaining only the 'what' (hoti) but not the 'why' (dioti) in their arguments - in other words, of assembling observed facts without uncovering their causes. Polybius adapts this accusation to his own field, historiography. For a historian to give up first-hand experience, he wrote, was as if a doctor proceeded without first-hand acquaintance of a case. While historians distinguished between experience (empeiria) and testimony (hypomnemata), medicine distinguished between testing (peira) and justification $(\log o s) .{ }^{53}$ According to Polybius's argument, armchair historians carried as little credibility as doctors who were familiar with all the logoi, but had never personally acted as 'surgeons,' that is, had never touched a body with their own hands (from the Greek *cheir-ourgos, which literally translates as 'hand worker').

51 Verrius Flaccus, De significatu verborum, 4. Quoted after Aulus Gellius, Noctes atticae, $5,18,2$.

$5^{2} \quad$ Polybius, Histories, $12,4$.

53 Polybius, Histories, 12, 25 . 
Indeed medicine, like historiography, is a discipline in which first-hand knowledge has always played a special role. In the medicine of the ancient world, the concept of autopsia went far beyond the mere execution of autopsies. The term denoted personal empirical experience, as evident in certain passages from Aristotle's writings on biology: ${ }^{4}$ a physician cannot simply rely on what patients tell him, but he has to see for himself, studying all the symptoms evident in the body, from the most obvious to the seemingly insignificant ones. Regardless of Polybius's desire to contrast physicians' first-hand acquaintance with second-hand knowledge, such a dichotomy was rarely discussed in the classical discourse on the art of healing. According to Galen, a doctor's knowledge should embrace the correct blend of autopsia, historia, and metabasis, where historia is simply the sum of others' empirical experiences, and metabasis a comparison of information accumulated by means of autopsia and historia. Hence first-hand acquaintance with a case and transmitted knowledge are perpetually intertwined. ${ }^{55}$

Dissections were prohibited by Christian authorities in late Antiquity and the Middle Ages, and therefore Hippocratic and Galenic texts corpuses remained to be the main authorities for medical knowledge. Their authoritative nature, in turn, removed the necessity of new discoveries based on one's own experience. As Ludwik Fleck explains: "In the first place they believed in Galen not because no observations were carried out, but because no observations in the present-day meaning of this word had been done, for there was no need to do it." 56

Autopsia and book learning would not stand in opposition to each other until the early modern period. The earliest attacks on academic anatomy, even before Andreas Vesalius' day, were launched by doctors such as Niccolò Massa who, in his Liber introductorius anatomiae (Venice, 1536), denounced those who dared "to write about matters that their eyes and their hands have never touched." ${ }^{57}$ He continued that "with the clouds of stale hand-written manuscripts, they obscure the brightest sunlight, as they are indifferent towards

54 Aristotle, History of Animals, 618a18, 620b23, 628b8; in Aristotle, History of Animals, ed. and trans. D'Arcy Thompson (Oxford, 1910).

Galen, Subfiguratio empirica, 9; quoted in Karl Deichgräber, Die griechische Empirikerschule: Sammlung der Fragmente und Darstellung der Lehre (Berlin, 1930, repr. 1965), 44-46.

57 Niccolò Massa, Liber introductorius anatomiae, sive dissectionis corporis humani (Venice, 1536), f. 3v: "neque oculis viderint neque manibus tetigerint." 
printed books." 58 Yet it was some time before the primacy of autopsia prevailed. As late as in 1599, André Du Laurens wrote in his Historia Anatomica that two equally valid paths towards truth existed in anatomy: autopsia and doctrina. ${ }^{59}$ While autopsia was based upon the dissection of human cadavers and the vivisection of animals, doctrina referred back to opinions officially endorsed by authorities, which made personal verification, according to Du Laurens, generally superfluous. But in seventeenth century, these positions were no longer part of a general consensus. By 1627 William Harvey's De motu cordis clearly affirmed the superiority of eye-witness observations over theoretical teachings. ${ }^{60}$ The appearance of new anatomical theaters was evidence of the emerging urge to experience things for oneself. At the first 'free' university of Padua (that is, free from any papal or secular authority), autopsies were conducted within the purpose-built teatro anatomico. Paradoxically, the ideal of first-hand observation, while in opposition to the written tradition, made extensive use of textual metaphors. For instance, in Caspar Bauhin's Theatrum anatomicum (Basel, 1592) the author describes dissections as a tool for rendering the "Book of Nature" (liber naturae) legible at last. ${ }^{61}$ Blumenberg comments on this:

It is therefore ironic in its own way that the language of early science once again makes metaphorical reference to books [...]. The question of how one could read this Book of Nature, in what language it could be read, in what language it would be written, and how one should go about discovering its grammar, was initially subsumed by the basic metaphorical layer of competition among books in which books are primarily placed alongside one another but secondarily pitted against one another. $^{62}$

$5^{8}$ Massa, Liber introductorius anatomiae, f. 4r: "sed ab aliis acceptis codicibus vetustate et in curia scriptorium impressorumque vitiates, lucidissimum solis lumen offuscarunt."

59 André du Laurens, Historia anatomica humani corporis, et singularum eius partium multis controversis et observationibus novis illustrata (Frankfurt, 1599), 10 and 15.

60 Gabriele Baroncini, "Harvey e l'esperienza autoptica," Forme di esperienza e rivoluzione scientifica (Florence, 1992), 145-173.

$61 \quad$ Caspar Bauhin, Theatrum anatomicum infinitis locis auctum (Basel, 1592).

62 Hans Blumenberg, Die Lesbarkeit der Welt (Frankfurt/Main, 1981), 18-19: "Es hat deshalb seine eigene Ironie, daß sich die Sprache der frühen Naturwissenschaft metaphorisch wieder auf das Buch bezieht. Es ist die Konkurrenz nicht nur zur Autorität der Bibel, sondern auch zu Aristoteles, die in der Metaphorik der beiden Bücher und ihrer Gleichrangigkeit angesagt wird. Die Frage, wie denn in diesem Buch der Natur gelesen werden könne, in welcher Sprache es geschrieben sei und wie man ihre Grammatik herauszufin- 
As Blumenberg has shown, the metaphor of the 'Book of Nature' was complemented by the metaphor of an intellectual 'Book of History.' 63 Nature recedes behind the things generated by its creatures. Clearly, the reference to the 'Book' in no way excludes autopsia, on the contrary, clear insight and the understanding of a text come to mean one and the same thing. In this context, seeing for oneself - whether nature or the world's past - is synonymous with reading for oneself. This does, however, bear implications for the question of what knowledge acquired through one's own effort actually means.

Autopsia as used in both medical history and historiography may, indeed, constitute, first and foremost, the acquisition of knowledge about the facts at hand by oneself. But it is necessary to distinguish between the acquisition of this knowledge by oneself, and its acquisition through one's own effort: in the former case, the subject is just an actor of knowledge, in the latter the subject is the author of knowledge. While in the former case, facts predate the epistemological process and are independent of it, in the latter, they result from it; hence the paradigm shift that is to be observed: it is not sufficient to acquire knowledge oneself, knowledge has to be self-generated. Rather than being decipherable from some Book of Nature or History, truths may be gathered from within the individual subject. As such, they can only be truths of reason. With time, the principle and the range of its validity has been extended, far beyond mere truths of reason. What is true needs to be grounded in oneself; what is true needs to be set up by the subject itself.

\section{Ex propria industria: Shaping the Modern Notion of Agency}

René Descartes is known to have attended postmortem examinations and vivisections in person, and these experiences left traces in his philosophical work. Beyond his famous experiment on an ox's eye ball, the wider importance of medicine in his philosophical method has also been discussed in recent scholarship. ${ }^{64}$ Although the role played by medicine and its empirical methods in Descartes' thought must, therefore, be acknowledged, the principle of autopsy as relevant to Descartes also requires analysis in a new, philosophical direc-

\footnotetext{
den hätte, schiebt sich erst über die metaphorische Grundschicht der Bücherkonkurrenz, in der primär Buch neben Buch, sekundär Buch gegen Buch steht" (emphasis original, translation mine).

63 Blumenberg, Lesbarkeit der Welt, 91.

64 For an overview see Vincent Aucante, La philosophie médicale de Descartes, preface by Jean-Luc Marion (Paris, 2006).
} 
tion. Significantly, his aim to find a system of medicine which, as he writes in a letter to Mersenne, would be "founded on infallible demonstrations" entailed a shift from sensory to mental vision. ${ }^{65}$ As Descartes perceived it, inner insight - the transparency of one's own mental activities - is the sole reason why no threat was posed by some malin génie. In his Discours de la méthode, Descartes also announced his goal of "the reformation of my own opinions, and basing them on a foundation wholly my own." ${ }^{16}$ Although Descartes defines science as a form of finding through one's own effort (invenire propria industria) and leading to "self-sufficiency" elsewhere self-sufficiency is the result, not a precondition of science, just as thought can only be held to function as a ground of certainty when it is transparent to subjects that have thought about a subject themselves. ${ }^{67}$

Descartes, therefore, whom Kant considered a "paragon of self-thought," presented a theory of thinking in which thoughts (according to the Regulae) are entirely "intellectual activities." 68 According to Christoph Menke, this refers to "the intellectual capacity of the I, which, by scrutinizing itself, has made itself its own foundation and can now methodically guide itself." ${ }^{99}$ Insofar as a person's knowledge is received from the external world, the risk of deception can never be fully ruled out. Only thought that is utterly "through one's own effort" (ex propria industria) stands on solid ground. ${ }^{70}$

This theory notably implies a reframing of the scholastic phrase propria industria or propria virtute. A concept discussed largely in the context of Christian theology, i.e. the extent to which Christ had undergone the Passion voluntarily and been resurrected through his own effort, had evolved into an

65 René Descartes, Letter to Mersenne of January 1630, eds. Charles Adam and Paul Tannery, CEuvres complètes [=AT] (Paris, 1897-1913), vol. 1, 106: "une médecine qui soit fondée en démonstrations infaillibles."

66 René Descartes, Discours de la méthode, II, 3. AT, vol. 6, 15: "réformer mes propres pensées, et de bâtir dans un fonds qui est tout à moi” (translation mine).

67 René Descartes, Letter to Hogelande, 8 February 1640. AT, vol. 3, 722.

68 According to Herder, who has transcribed Kant's early lectures on logic, the original wording is "Muster im selbst denken," Kant, Akademie-Ausgabe, vol. 24 (1966), 4, 1l. 26-27. Further on the notion of Selbstdenken in Kant, and its context, see Lothar von Kreimendahl, "Kants vorkritisches Programm der Aufklärung," in Reiner Klemme, ed., Kant und die Zukunft der europäischen Aufklärung (Berlin, 2009), 124-142, at 133. Fort the Descartes quote, see Regulae ad directionem ingenii, 3,4. AT, vol 10, 368: "actiones intellectus nostri."

69 Christoph Menke, Force: A Fundamental Concept of Aesthetic Anthropology, trans. Gerrit Jackson (New York, NY, 2013), 10.

70 Descartes, Regulae ad directionem ingenii, 10,1. AT, vol. 10, 403. 
essential feature of subjectivity theory. ${ }^{71}$ It could now be used to justify the other precepts of the modern self: self-determination, autonomy, self-control, and self-regulation. In contrast to Petrarch's view that freedom comprises "being with oneself" (secum esse), the modern self comes into its own only through self-action. In the school of thought established by Pico della Mirandola, humans must become sculptors of themselves, shaping and molding their being (sui ipsius [...] plastes et fictor)..$^{72}$ Man needs to be a sculptor who chisels out his form from the very material nature has given him. Through such self-design, the subject fashions itself through an act of self-creation. Ernst Cassirer summed up this thinking thus: "As soon as we proceed to the order of value, we find a reversal of the temporal succession of the man of 'nature' and the man of 'art' - a reversal, that is, of the primus homo and the secundus homo: the second in time becomes the first in value."73

In the wake of Pico's image of the subject fashioning itself, seventeenthcentury philosophy developed either the conception of self-generating, spontaneous substances (Spinoza), or that of monads acting out of their own depths (Leibniz). The fortune of the Leibnizian concept of the "notion of an individual substance, which contains all its phenomena in such a way that nothing can happen to a substance that does not come from its own depths" explains in part why derived, external knowledge, such as knowledge from testimony, was, by and large, marginalized. ${ }^{74}$ The requirement to speak on one's own behalf even increased, and became a battle cry for the eighteenth- and nineteenth-century philosophy of subjectivity. This is particularly true of the thinkers associated with existentialism and its forerunners.

During the Enlightenment Friedrich Heinrich Jacobi, for instance, rejected 'second-hand knowledge,' which yet relied on proofs while asserting that one's own, immediate knowledge required no witnesses. ${ }^{75} \mathrm{~A}$ careful reader of Jacobi, Søren Kierkegaard criticized what he deemed to be a pathology of the anonymity and "ventriloquism" of his time, and characterized it as "a world which

71 Thomas Aquinas, Summa theologiae [Opera omnia, Leonine edition, Rome 1888-1906], IIIa, 53,4 sc. "quod Christus propria virtute resurrexit."

72 Pico della Mirandola, Oration on the Dignity of Man, eds. Michael Papio Borghesi and Massimo Riva (Cambridge, 2012), 116.

73 Ernst Cassirer, The Individual and Cosmos in Renaissance Philosophy, trans. Mario Domandi (New York, NY, 1963), 97.

74 Gottfried Wilhelm Leibniz, Letter to Arnauld, 28 November (8 December) 1686; in Leibniz, Philosophical Essays, eds. and trans. Roger Ariew and Daniel Garber (Indianapolis, IN and Cambridge, 1989), 80: "qui ne lui naisse de son propre fonds." des Deutschen Idealismus (Frankfurt/Main, 2004), 38. 
is quite unaccustomed to hearing an I."76 Then again, Kierkegaard considered his own role to be that of a "forerunner until he comes who in the strictest sense says: I."77 The 'I' to which he was referring was not an autobiographical one, given his literary style of writing in a diversity of voices. "It became my task to create author-personalities and let them enter in the actuality of life in order to get men a bit accustomed to hearing discourse in the first person," he wrote, finding that "truth' cannot possibly be served by ventriloquism."78

One could easily write a history of this intellectual thread, which extends all the way from Jacobi, via Kierkegaard, through to twentieth-century existentialism, with figures such as Sartre and Heidegger: self-agency, doing things out of one's own capacities, will be found to be one of its most central motives. In Being and Time Heidegger stresses the "resoluteness" (Entschlossenheit) which testifies to an inner "ability to be oneself" (Selbstseinkönnen), and which thus pushes back the realm of anonymity (das Man). According to Günther Anders, one of Heidegger's earliest readers and critics, Heidegger's call for existential resoluteness reminds of the legendary Baron Munchhausen, who believed he could pull himself out of a swamp by pulling on his own ponytail: "The others, doxa, prejudice, customs, are nothing but the loam sticking to the self's foot and hindering his being himself. It is out of this loam of 'Man,' that 'Dasein' has to drag itself, like Munchhausen seizing himself by his own hair." ${ }^{\text {'D }}$

\section{The Philosopher as Autodidact}

Yet another important line of intersection between self-knowledge and selfagency is that of self-education. In his dialogue On the Teacher, Augustine rhetorically asks: "Who is so foolishly curious as to send his son to school to learn what the teacher thinks?"80 Autodidacticism, in the sense of the rejection of others' authorities, is, indeed, one of the forms adopted by the propria industria imperative. Leibniz, for one, insists he was "nearly self-taught," and that rather than "filling my mind with trifles [...][,] things that are accepted on the

${ }_{7} 6$ Søren Kierkegaard, Papirer, 16 vols. in 22, ed. Niels Thulstrup (Copenhagen, 1968-1978), vol. 8, B 88, 183. Idem, Søren Kierkegaard's Journals and Papers, eds. and trans. Howard V. and Edna H. Hong, 7 vols. (Bloomington, 1999), vol. 6, 178.

77 Kierkegaard, Journals and Papers, vol. 6, 178.

78 Ibid.

79 Günther Anders (Stern), "On the Pseudo-Concreteness of Heidegger's Philosophy," Philosophy and Phenomenological Research, 8 (1948), 337-371, at 354.

$80 \quad$ Augustine, De magistro, 14, 45; in Augustine, On the Teacher, trans. Peter King (Indianapolis, IN, 1995). 
authority of teachers rather than because of arguments," he had "probed all the way to the depths of each subject and arrived at its very principles, from which everything I extracted could be discovered by my own efforts." 81

No doubt the figure of the autodidact has much more ancient origins. One early - and illuminating - example is the singing contest between Domodocus and Phemius in Homer's Odyssey. Phemius boasts that, unlike Domodocus (whom he accuses of having copied his songs from others), he has taught his own songs to himself as an autodidaktos, that is, composed them on his own. ${ }^{82}$ Nevertheless - and this might surprise modern readers - he hastens to add that, while he has discovered this aptitude within himself, it remains to be a gift from the Muses. The assertion that the act of writing literature is different from an act of rewriting does not rule out the agency of divine inspiration, for the singer has truly been implanted with the knowledge, or been bestowed it drop by drop $(e m p h u \bar{o}) .{ }^{83}$

The term autodidaktos was still employed in late antiquity in the philosophy of religion, by thinkers such as Philo of Alexandria, for whom it solely signified knowledge that had not been borrowed from others. His treatise On Flight and Finding describes four types of seekers. The fourth type, the 'self-learnt and self-taught sage' (automathēs kai autodidaktos) does not, according to Philo,

by searchings and practicings and toilings gain improvement, but as soon as he comes into existence he finds wisdom placed ready to his hand, shed from heaven above and of this he drinks undiluted draughts, and sits feasting, and ceases not to be drunken with the sober drunkenness which right reason brings. ${ }^{84}$

Philo's remarks venture to explain why there is no contradiction between an autodidaktos and a theodidaktos, the divinely instructed sage of St. Paul's First Epistle to the Thessalonians. ${ }^{85}$

Abraham Malherbe has argued that, regardless of this, the allusion to autodidaktos and theodidaktos in the theology of revelation, even during St. Paul's

81 Gottfried Wilhelm Leibniz, "Preface to a Universal Characteristics," (1678), in Leibniz, Philosophical Essays, 5-10, at 6.

82 Homer, Odyssey, 22, 347 .

83 See Jacqueline Assael, "Phémios autodidaktos," Revue de philologie, 75 (2001), 7-21.

84 Philo of Alexandria, De fuga et inventione, ed. Paul Wendland, Philonis Alexandrini opera quae supersunt (Berlin, 1896-1915), vol. 3 (1898, repr. 1962), 166 (translation mine).

851 Thessalonians 4,9; see Calvin J. Roetzel, "Theodidaktoi and Handwork in Philo and 1 Thessalonians," in Albert Vanhoye, ed., L'apôtre Paul: Personnalité, style et conception du ministère (Leuven, 1991), 324-331. 
lifetime, certainly deserves a polemic interpretation, $v i z$. as a reframing and appropriation of another dominant reading of the epistemological paradigm. In the first centuries $\mathrm{AD}$, the concept of autodidaktos was predominantly associated with the Epicurean tenet of first-hand experience. ${ }^{86}$ It agrees with Epicurus's claim that he had never had a teacher, and that he was his own student in all respects. This claim, attested by Cicero and Diogenes Laertius, among others, has been called into question many times afterwards, including by Hegel. And yet Epicurus's programmatic autodidacticism has also been held up as exemplary by many, including Marx, who lauded it in an early treatise in a comparison of Democritus' and Epicurus' philosophies of nature:

While Democritus seeks to learn from Egyptian priests, Persian Chaldeans and Indian gymnosophists, Epicurus prides himself on having had no teacher, on being an autodidact. There are some people, he says, according to Seneca, who struggle after truth without assistance. Among these people he has himself traced out his path. And it is they, the autodidactic, whom he praises most. The others, to his mind, are of the second rank. ${ }^{87}$

To Marx, the episode of St. Paul subsuming the autodidaktos under the concept of the theodidaktos, and thereby considering self-teaching just a superficial understanding of what is, in fact, a godly instruction, is nothing but a form of religious subjugation, whereby ecclesiastic institutions make sure to keep the flock away from autonomous thinking.

Ernst Bloch has identified similar autodidactic philosophers, whom he describes as examples of successfully intellectually emancipated figures. In his book Avicenna und die aristotelische Linke ('Avicenna and the Aristotelian Left'), Bloch endeavors to rehabilitate Arabic culture as one of the "headwaters of our Enlightenment." 88 In his lectures and writings, he refers to the fictional character of the philosophus autodidactus who appears in Ibn Tufayl's novel Hayy Ibn Yaqzan and, according to Bloch, reinforces "the core belief of the Enlightenment: that humanity needs no beliefs besides reason itself." ${ }^{89}$ In this philosophical robinsonade, Ibn Tufayl (1110-1185) describes the life of a boy

86 Abraham J. Malherbe, Paul and the Thessalonians: The Philosophical Tradition of Pastoral Care (Philadelphia, 1987), 104-105.

87 Karl Marx, Differenz der demokritischen und epikureischen Naturphilosophie (1841), in MEGA [=Marx-Engels-Gesamt-Ausgabe] vol. I 1/1 (Berlin, 1975), 28 (emphasis original, translation mine).

88 Ernst Bloch, Avicenna und die aristotelische Linke (Berlin, 1952), 11 (translation mine).

89 Ibid., 26 (translation mine). 
named Hayy ibn Yaqzan, who is raised by animals on a desert island in the Indian Ocean and discovers the principles of nature and reason on his own. ${ }^{90}$ Irrespective of whether he was abandoned and left to his fate on the island (like, later, Kasper Hauser) or has simply sprung to life by spontaneous generation, the autodidact gradually achieves insight in the principles of the world through his own intuition and use of intellect. As has been emphasised elsewhere, Ibn Tufayl's island novel must be interpreted as a response to Avicenna's 'Floating Man' thought experiment: ${ }^{91}$ even if nothing alerts us to our own existence, whether by bodily proprioception or through the testimony of others, we still have access to our inner states.

The story of Hayy ibn Yaqzan was very popular not only in the Arabic-speaking world, but also in the West. ${ }^{92}$ According to Otto Luschnat, the novel's Latin translation (Philosophus autodidactus) is the earliest example of the Latin adoption of the Greek word autodidaktos. ${ }^{93}$ The English translation of Ibn Tufayl's thought experiment was prepared by Edward Pococke in 1671; and even Leibniz is praising Pococke's translation in a letter to the naturalist Albrecht von Holten, in which he also states his familiarity with the works of Ibn Tufayl and his contemporary Averroes. Leibniz considers Hayy ibn Yaqzan an example of the autodidact that he also defends fervently in other contexts. As he points out in a letter sketch to Malebranche: "More frequently will he who does not understand an art find something new than he who does, he who is selftaught sooner than those who are not; for he enters by a road and gate unknown to others, and gains a different view of things. He admires that which is new, while others pass it by as something well known." ${ }^{4}$ When commenting on his reading of the Philosophus autodidactus, Leibniz links it with Augustine,

9o For an English translation see Lenn Evan Goodman, Ibn Tufayl's Hayy ibn Yaqzān: A Philosophical Tale (New York, NY, 1972).

$91 \quad$ Ibid., 195 .

92 G.A. Russell, "The Impact of the Philosophus autodidactus: Pocockes, John Locke, and the Society of Friends," in G.A. Russell, ed., The 'Arabick'Interest of the Natural Philosophers in Seventeenth-Century England (Leiden, 1994), 224-265.

Edward Pococke, Philosophus autodidactus sive epistola Abi Jafaar Ebn Tophail de Hai Ebn Yodkhan in qua ostenditur quomodo ex inferiorum contemplatione ad superiorum notitiam ratio humana ascendere possit (Oxford, 1671). See Otto Luschnat, "Autodidaktos: Eine Begriffsgeschichte," Theologia viatorum, 8 (Berlin and New York, NY, 1962), 157-172.

94 Sketch of a Letter to Malebranche from 22 June (2 July) 1679. "Saepius aliquid novi invenit, qui artem non intelligit, quam qui intelligit. Item autodidaktos quam alius, Irrumpit enim per portam viamque aliis non tritam, aliamque rerum faciem invenit. Omnia nova miratur, in ea inquirit, quae alii quasi comperta praetervolant." Gottfried Wilhelm Leibniz, Politische Schriften. Akademie-Ausgabe, vol. 4.7: Writings 1697-1699 (Berlin, 2011), 751. 
whom he sees as another defender of self-acquired evidence: it is not other people who can convince us, but only the truth which dwells in our intelligence..$^{95}$

The reception of the Philosophus autodidactus is also interesting in other respects. Notably, Pococke's translation had been commissioned by the AngloIrish naturalist Robert Boyle. Thanks to Steven Shapin and Simon Schaffer's Leviathan and the Air Pump, Boyle is now regarded as the embodiment of a collective practice of science which replaces Hobbes's epistemological individualism. However, such a broad-brush picture would be similarly misleading. Boyle actually also retained some basic elements of solipsistic epistemology, as demonstrated by a fragment from the island novel (clearly inspired by Ibn Tufayl) that he published under the title The Aspiring Naturalist. ${ }^{96}$ This narrative features its own autodidactic philosopher (Authades, the 'self-willed') and describes to a European visitor (named Philaretes) the philosophical knowledge that the islanders have acquired on their own. ${ }^{97}$

In short, during the Age of Enlightenment, the autodidact became a figure of "intellectual emancipation," to quote Jacques Rancière. ${ }^{98}$ Thinkers through their own effort liberated themselves from the superior power and prevailing violence of alien authorities. Whereas the adoption of second-hand knowledge always bears the risk of an alien mancipatio (from manus, 'hand,' and $\mathrm{ca}$ pere, 'to capture, seize'), ex propria industria thought holds the key to mental 'e-mancipation.' Only 'under one's own steam' can true freedom be attained. This includes the assurance, which Jean Améry pursued to its radical conclusion, that in extreme cases, one may choose to "lay hands on oneself" (i.e., commit suicide) in order to prove one's own independence until the very last possible moment. ${ }^{99}$

95 Leibniz, Philosophische Schriften. Akademie-Ausgabe, vol. 6.4: Writings 1677-169o, Part B (Berlin, 1999), 1681: "non homines nos persuadent, sed veritas quae intus est in domicilio cogitationis nostrae." The passage Leibniz refers to is from Augustine, Confessiones, book 11, chap. 3 .

96 Robert Boyle, "A Fragment of the Aspiring Naturalist: A Philosophicall Romance," (1686) The Boyle Papers, vol 9, fols. 42v-43r (<http://www.bbk.ac.uk/boyle/boyle_papers/bpo9_ docs/bp9_042v-043r.htm>, accessed 8 March 2017).

97 Gerald J. Toomer, Eastern Wisedome and Learning: The Study of Arabic in SeventeenthCentury England (Oxford, 1996), 222.

98 Jacques Rancière, The Ignorant Schoolmaster: Five Lessons in Intellectual Emancipation, trans. Kristin Ros (Palo Alto, CA, 1991).

99 Jean Améry, On Suicide: A Discourse on Voluntary Death, trans. John D. Barlow (Bloomington, IN, 1999). 


\section{Instead of a Conclusion: The Spider and the Bee}

The preceding archaeological forays into fields of knowledge as diverse as history, medicine, subjectivity theory, and education corroborate the preeminence of the trope of propria industria, the acquisition of knowledge under one's own steam, from Antiquity to the early modern period. This preeminence in itself may explain why, in the history of knowledge, second-hand knowledge has often been viewed with suspicion. It seems that the marginalization of testimony cannot simply be explained to be a function of modern-day subjectivism. Rather, the theme of knowledge by self-action draws on multifarious sources.

Our brief archaeological probings into propria industria have covered a wide territory: we first investigated the preference for the sense of vision over hearsay in archaic epic poetry and philosophy, then examined the birth of historiography out of the concept of the eye witness, and then went on to explore the trope of autopsia in the emerging medical discourse of the medieval and early modern periods. Progressing through history, we then considered the maxim of propria industria in the works of Descartes and other early modern philosophers, and finally explored the emancipatory pledge of autodidactics. First, these intellectual excavations illuminate the question why knowledge from testimony has often been marginalized or even condemned; secondly, they cast the diagnosis of forgetfulness of testimony in a rather different light.

As shown, a near-consensus in the contemporary testimony debate holds that second-hand knowledge has been rejected because it is merely taken over and not generated anew. Knowledge from testimony shall remain an epistemological phantom for as long as epistemology remains dominated by an "individualistic bias" and a fundamentally solipsistic model of knowledge acquisition constructed around the conception of an underlying and preexisting self. Hence it is the express aim of an interdisciplinary epistemology to demonstrate the possibility of self-sufficient, independent knowledge acquisition existing side by side with the generation of knowledge by others.

Such a picture is painted with too broad a brush stroke, however, and it reduces a complex development to a narrow modern perspective. This picture also establishes the very line of demarcation it was originally intended to subvert. While evidence is provided to demonstrate that a witness not only mediates knowledge, but also generates it, knowledge acquisition through one's own effort is, by contrast, still largely explained in terms of a rather static understanding of the self. In other words, the philosophical lens of subjectivity restricts propria industria to the propria and loses sight of the industria. 
Above and beyond the complementarity thesis - according to which we not only acquire knowledge by ourselves, but owe most of what we know to others - the problem of testimony reverts directly to the peculiar generativity of knowledge. Too often this generativity is misappropriated when, in the selfagency of propria industria, the self is taken to be both the starting and finishing point. While knowledge through oneself is mistaken with knowledge about oneself, the self remains indebted to the philosophical ideal of egocentrism, suppressing the causative element in favor of a reflexive entity. Reapplying this to the diagnosis of the forgetfulness of testimony, we find that forgetfulness of testimony would then be rooted not in a solipsistic bias, but instead in a primacy of self-agency. Such a shift in focus prompts a revision of the dichotomy of mediated versus unmediated knowledge in favor of a diversity of media of knowledge acquisition.

I shall conclude with an image. Francis Bacon devised a famous allegory to illustrate the distinction between autopoietic and heteropoietic media of knowledge acquisition. Here, the rationalist is typified by a spider, which spins its web out of its own material, whereas a naturalist resembles a bee, whose honey relies on pollen from alien flowers while essentially the result of a process of inner elaboration. Moving beyond an overly simplistic dichotomy of knowledge through oneself vs. knowledge through others, of a generative creation vs. a merely reproductive appropriation - and this is perhaps what Bacon's allegory is getting at - the problem of testimony invites us to identify the particular type of 'through' in question, the essential operative mediality behind knowledge acquisition. 